\title{
Dikerogammarus villosus (Amphipoda : Gammaridae) : another invasive species newly established in the Moselle river and French hydrosystems
}

\author{
S. Devin 1 \\ J.N. Beisel ${ }^{1}$ \\ V. Bachmann ${ }^{1}$ \\ J.C. Moreteau ${ }^{1}$
}

Keywords : Dikerogammarus villosus, D. haemobaphes, exotic gammarid, French hydrosystem, Moselle, Danube, Rhine, morphs, Ponto-Caspian basin.

Based on field observations performed in 1999 and 2000, the exotic amphipod Dikerogammarus villosus is now well established throughout the navigable sector of the River Moselle in France. D. villosus co-occurs with Gammarus pulex, G. tigrinus and $D$. haemobaphes, another recent exotic species found in this tributary of the River Rhine. The maximal size of individuals of $D$. villosus collected $(15.7 \mathrm{~mm}$ ) is lower in the River Moselle than in other basins, where this species could reach up to 30 $\mathrm{mm}$ (Neseman et al. 1995). Nevertheless it represents the largest gammarids found in the French sector of the River Moselle. Other particular traits are its wide phenotypic plasticity, varying from a melanic to a striped form, and its predatory behavior. These particular traits may favour the establishment of this species on a recipient ecosystem. The occurrence of $D$. villosus was noted in the Alsace Canal and in the River Rhône, showing that its immigration across French hydrosystems is still in progress.

Dikerogammarus villosus (Amphipoda : Gammaridae) : une nouvelle espèce invasive récemment établie dans la Moselle et les hydrosystèmes français

Mots clés : Dikerogammarus villosus, D. haemobaphes, Gammaridae exotiques, hydrosystèmes français, Moselle, Danube, Rhin, morphotypes, bassin Ponto-Caspien.

Sur la base de campagnes d'échantillonnage réalisées en 1999 et en 2000 , nous avons constaté que l'amphipode exotique Dikerogammarus villosus est désormais bien établi sur le secteur navigable de la Moselle française. $D$. villosus cohabite avec Gammarus pulex, $G$. tigrinus et $D$. haemobaphes, une autre espèce exotique récemment trouvée dans cet écosystème. La taille maximale des individus de l'espèce $D$. villosus récoltés $(15,7 \mathrm{~mm})$ est moindre dans la Moselle que dans d'autres bassins, l'espèce pouvant atteindre $30 \mathrm{~mm}$ (Neseman et al. 1995), mais représente les plus grands Gammaridae du secteur français de la Moselle. Des traits particuliers, tels que sa grande plasticité phénotypique, allant d'une forme mélanique à une forme zébrée, et son comportement prédateur, pourraient favoriser l'établissement de cette espèce dans de nouveaux écosystèmes. La présence de $D$. villosus a été notée dans le canal d'Alsace et dans le Rhône, montrant que son immigration au sein des hydrosystèmes français est toujours en cours.

\section{Introduction}

Invasion of freshwater ecosystems by exotic species may involve plants, vertebrates or invertebrates. Among the invertebrate invaders, mollusc and crusta-

\footnotetext{
1. UPRES "Ecotoxicité, Biodiversité et Santé Environnementale", Equipe de Démoécologie, Université de Metz, UFR SciFA Campus Bridoux, Av. du Général Delestraint, 57070 Metz, France. E-mail: simon.devin@umail.univ-metz.fr
}

cean species are often numerous and successful (Van der Velde et al. 2000).

In Central and Western European inland waters, many recent exotic invaders arrived from the Ponto-Caspian Region (Black Sea, Azov Sea and Caspian Sea). One of the most important connections between Eastern and Western European ecosystems is the MainDanube Canal, completed and officially opened in 1992 (Van der Velde et al. 2000). It links the Danube River with the Rhine catchment area via the Main tributary. This Canal has become a viable migration route between the Black Sea and the North Sea for two 
reasons. First, water transfer from the Danube to the Main (the upper section of the canal is continuously filled with water from the Danube basin) allows some mobile species to easily migrate westwards ( $\mathrm{Bij}$ de Vaate \& Hulea 2000). Secondly, shipping traffic, in both directions, facilitates the dispersal of species (attached to ship hulls or transported in ballast water) across natural barriers and hence increases opportunities for the immigration of exotic species. For example, the colonization of the Upper Danube via the Main-Danube Canal by the clam Corbicula fluminea, established in the River Rhine since 1986, was observed in 1997 (Tittizer \& Taxacher 1997), with a range extending to the Romanian part of the River Danube (Bij de Vaate \& Hulea 2000).

Recently, the same route was taken in the opposite direction by the gammarid Dikerogammarus villosus. This species is widely distributed in the lower reaches and the delta of the River Danube (Nesemann et al. 1995). D. villosus was collected for the first time in several sites in Austria in 1989, in the Upper Danube in 1992 (Nesemann et al. 1995), and spread along the Main-Danube Canal (1993) and the River Main (1994) to the River Rhine in 1995 (Bij de Vaate \& Klink 1995, Van der Velde et al. 2000).
Macroinvertebrate sampling was performed along the French part of the Rivers Moselle and Meurthe to (1) confirm the extension of Dikerogammarus villosus into Western Europe and (2) evaluate its importance within crustacean assemblages along the French part of the Rivers Moselle and Meurthe.

\section{Material and methods}

\subsection{Study areas and sampling design}

Following qualitative observations of Dikerogammarus villosus on the French part of the River Moselle in October 1999, field sampling was done at 9 stations in June/July 2000. All nine stations were located on the French sector of the River Moselle, in Northeastern France (Fig. 1). Monthly or fortnightly physico-chemical measurements were recorded during the period January-December 1999 by the Regional Office of the French Environmental Ministry. Data of these measurements were obtained from a regional, freshwater database, the 'Banque de l'Eau Rhin-Meuse - Réseau National des Données sur l'Eau'. Table 1 presents minimum, median and maximum values for major parameters.

Samples were collected at each station with a handnet, allowing for sampling in a wide range of organic

Table 1. Yearly median, minimal and maximal values for major water quality parameters for the Moselle River and the Meurthe River, one of its tributaries, in 1999.

Tableau 1. Valeurs annuelles moyennes, minimales et maximales de paramètres majeurs de la qualité de l'eau pour la Moselle et un de ses affluents, la Meurthe, en 1999.

\begin{tabular}{|c|c|c|c|c|c|c|c|c|c|c|}
\hline \multicolumn{2}{|c|}{ Parameters } & \multirow{2}{*}{$\begin{array}{c}\text { Sierck } \\
289.5\end{array}$} & \multirow{2}{*}{$\begin{array}{c}\text { Cattenom } \\
278.5\end{array}$} & \multirow{2}{*}{$\frac{\text { Argancy }}{286}$} & \multirow{2}{*}{$\begin{array}{c}\text { Ars } \\
335.5\end{array}$} & \multirow{2}{*}{$\begin{array}{c}\text { Vandières } \\
313.5\end{array}$} & \multirow{2}{*}{$\begin{array}{c}\text { Liverdun } \\
15.8\end{array}$} & \multirow{2}{*}{$\begin{array}{c}\text { Velle } \\
13.75\end{array}$} & \multirow{2}{*}{$\begin{array}{c}\text { Bouxières } \\
786.5\end{array}$} & \multirow{2}{*}{$\begin{array}{c}\text { Rosières } \\
19.75\end{array}$} \\
\hline Cl & Median & & & & & & & & & \\
\hline $\mathrm{mg} / \mathrm{l}$ & minimum & 29 & 37.6 & 38.3 & 32.2 & 140 & 12.2 & 8.7 & 47.5 & 10.8 \\
\hline & maximum & 447 & 442 & 526 & 520 & 448 & 27.1 & 23.6 & 1180 & 27.5 \\
\hline Conductivity & Median & 1398 & 1370.5 & 1392 & 1364.5 & 1268.5 & 328.5 & 208.5 & 2965 & 278.5 \\
\hline \multirow[t]{2}{*}{$\boldsymbol{\mu S} / \mathbf{c m}$} & minimum & 147 & 146 & 161 & 145 & 640 & 145 & 108 & 208 & 129 \\
\hline & maximum & 2120 & 1952 & 1890 & 1970 & 1720 & 502 & 438 & 3830 & 360 \\
\hline \multirow[t]{3}{*}{ pH } & Median & 7.4 & 7.4 & 7.35 & 7.4 & 7.5 & 7.3 & 7.4 & 7.85 & 7.4 \\
\hline & minimum & 7 & 6.8 & 6.7 & 6.9 & 6.7 & 6.7 & 6.8 & 7.1 & 6.6 \\
\hline & maximum & 8.8 & 8.6 & 8.6 & 8.5 & 8. & 8.1 & 8.1 & 8.9 & 8.1 \\
\hline
\end{tabular}




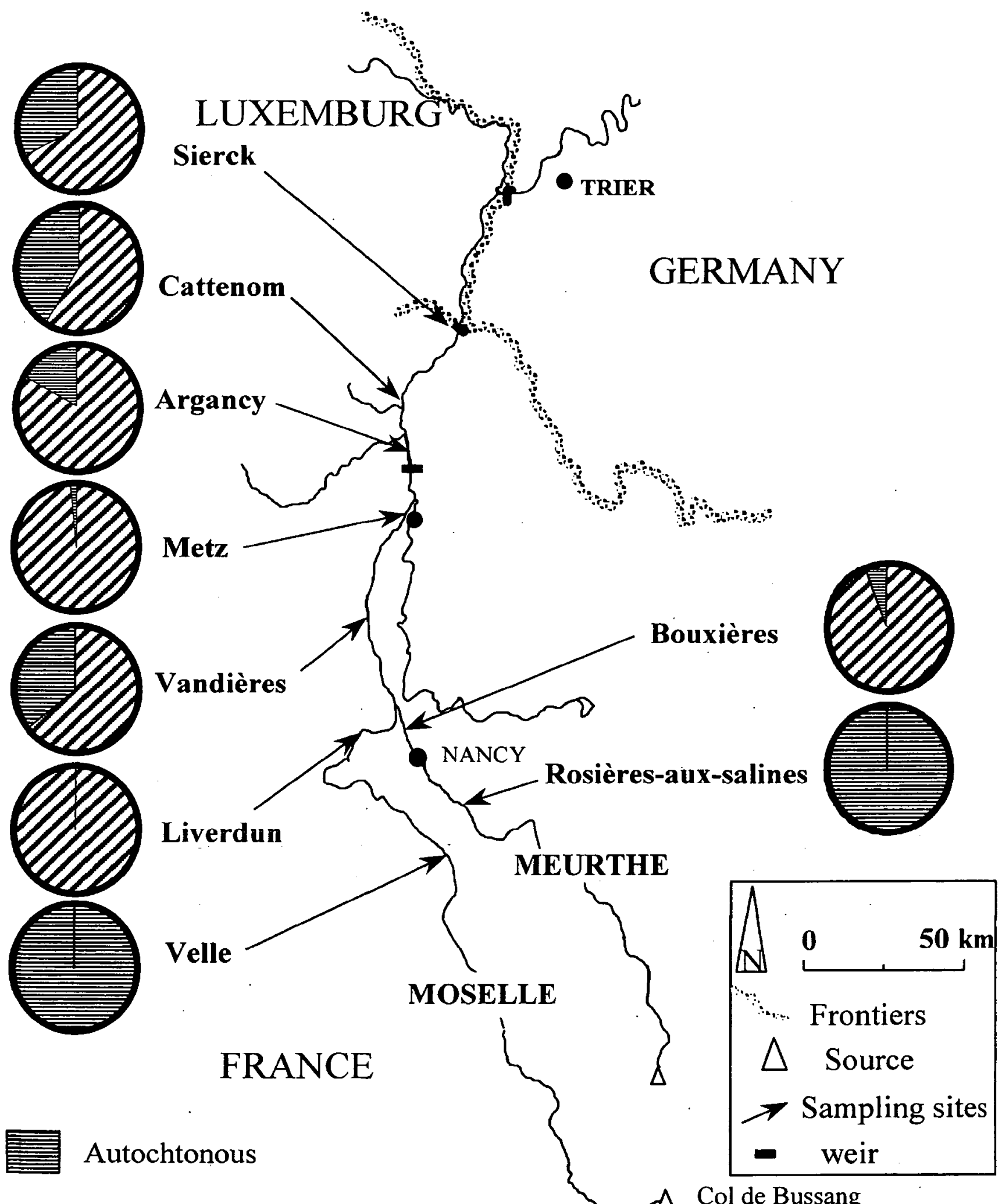

Invasives

Fig. 1. Map showing sampling sites along the Moselle River and its tributary, the Meurthe. Pie charts show abundance of exotic amphipods from the Ponto-Caspian region (Dikerogammarus villosus, D. haemobaphes, Corophium curvispinum) based on at least 100 individuals collected per site, except at Vandières, Velle and Rosièresaux-Salines, where respectively 41,19 and 7 specimens of Gammaridae were found.

Fig. 1. Carte montrant les sites échantillonnés le long de la Moselle et d'un de ses affluents, la Meurthe. Les camemberts montrent l'abondance relative des amphipodes exotiques originaires du bassin Ponto-Caspien (Dikerogammarus villosus, D. haemobaphes, Corophium curvispinum) basée sur au moins 100 individus par site, sauf à Vandières, Velle et Rosières-aux-Salines, où respectivement 41,19 et 7 individus ont été trouvés. 
microhabitats (aquatic vegetation and/or tree roots and/or organic debris) near the river bank. Sampling was carried out at each station until approximately 100 Gammaridae were caught. 41, 19 and 7 specimens of Gammaridae were found respectively at three stations : Vandières, Velle and Rosières-aux-Salines. Organic habitats were scarce within these sectors and did not shelter many Gammaridae. Formaldehyde and alcohol solutions, where gammarids natural coloration faded rapidly, cannot be used for preservation if the different morphs (see Nesemann et al. 1995, and "Results" section for description) have to be separated. So samples were frozen before separation and identification of the macroinvertebrates.

\subsection{Examination of biological samples}

The species were identified according to Carausu et al. (1955).

D. villosus specimens were measured to the nearest $0.1 \mathrm{~mm}$ from the base of the first antenna to the base of the telson under a stereomicroscope fitted with an eyepiece micrometer. Following Muskó (1993) on D. haemobaphes, animals longer than $5.4 \mathrm{~mm}$ were sexed (females on the basis of the presence of oostegites, males on the basis of the presence of sexual plates).

\section{Results and discussion}

In October $1999, D$. villosus was observed in the $\mathrm{Ri}-$ ver Moselle at each of the four prospected stations : Sierck-les-Bains, Cattenom, Argancy and Metz, and this species represents between 25 and $50 \%$ of the Gammaridae population.

In June and July 2000 , further study of macroinvertebrate communities led to the discovery that five different species of gammarids occur in the Moselle River : Gammarus pulex, G. roeseli, G. tigrinus, Dikerogammarus villosus and D. haemobaphes. G. pulex is native of and widespread in Western Europe. G. roese$l i$ was introduced in Western Europe in 1845, after the opening of the Ludwigskanal between the Rivers Rhine and Danube (Nesemann et al. 1995). The North American G. tigrinus was introduced into Germany (Weser and Werra River) as fish food in 1957 and progressively colonized the Rhine catchments (Van der Velde et al. 2000). These three speciès have coexisted in the French River Moselle since the 1990's. Dikerogammarus villosus and D. haemobaphes are two Ponto-Caspian gammarid species which recently colonized the Rivers Main and Rhine. During this sampling program, the exotic amphipod Corophiidae Coro- phium curvispinum, established in the River Moselle since 1994 (Bachmann et al. 1995), was also collected.

Focusing on Dikerogammarus villosus, it occurred throughout the navigable sector of the River Moselle but was still absent from the upstream sector and from the Meurthe River. The Velle and Rosières-aux-Salines sampling stations did not shelter a great density of gammarids, only 19 and 7 specimens were found respectively. In macrophytes and organic debris near the banks, we observed proportions of $D$. villosus specimens ranging from 11.1 to $91.8 \%$ of gammarids depending on the station sampled (Fig. 2). These proportions are valid for this kind of micohabitats, in summer, but could be different in the channel or in lotic habitats. Dikerogammarus haemobaphes was found for the first time in the River Moselle, at two locations (Sierck-les-Bains and Liverdun) and in lower numbers than $D$. villosus. The two Dikerogammarus species cohabited with an autochthonous species, Gammarus pulex, and with Gammarus tigrinus. G. roeseli and Dikerogammarus were never found together in the River Moselle (Fig. 2).

The relative abundance of invasive amphipods was high in the navigable sector of the River Moselle. The absence of invasive species upstream could be explained by inadequate conditions for their establishment or the fact that individuals have not yet had the opportunity to move into this sector. The invasion of $D$. villosus, into the Moselle catchment and other French hydrosystems is considered to be still in progress. Specimens of this species were observed in various samples collected in summer 2000 in the Alsace Canal at Fessenheim, where it represents $90 \%$ of gammarids, and in the River Rhône.

In the River Moselle, observations demonstrated that $D$. villosus can survive and develop in water with high levels of conductivity, up to $2000 \mu \mathrm{S} / \mathrm{cm}$ (Table $1)$. Considered as a brackish water species, $D$. Villosus is salt-tolerant (Van der Velde et al. 2000) but also supports relatively low values of conductivity - mean of $328 \mu \mathrm{S} / \mathrm{cm}$ at Liverdun - (Table 1). We noticed that $G$. tigrinus and $G$. pulex supported the high salinity at the Bouxières station with a conductivity level of at least $2965 \mu \mathrm{S} / \mathrm{cm}$ for half of the year (median values) and a chloride concentration of $786 \mathrm{mg} / \mathrm{l}$. For aquatic ecosystems colonized by $D$. villosus, Nesemann et al. (1995) suggested that its abundance depended on water discharge.

Exotic amphipod species represented between 60 and $100 \%$ of amphipod specimens collected on the downstream sectors of the Rivers Moselle and 


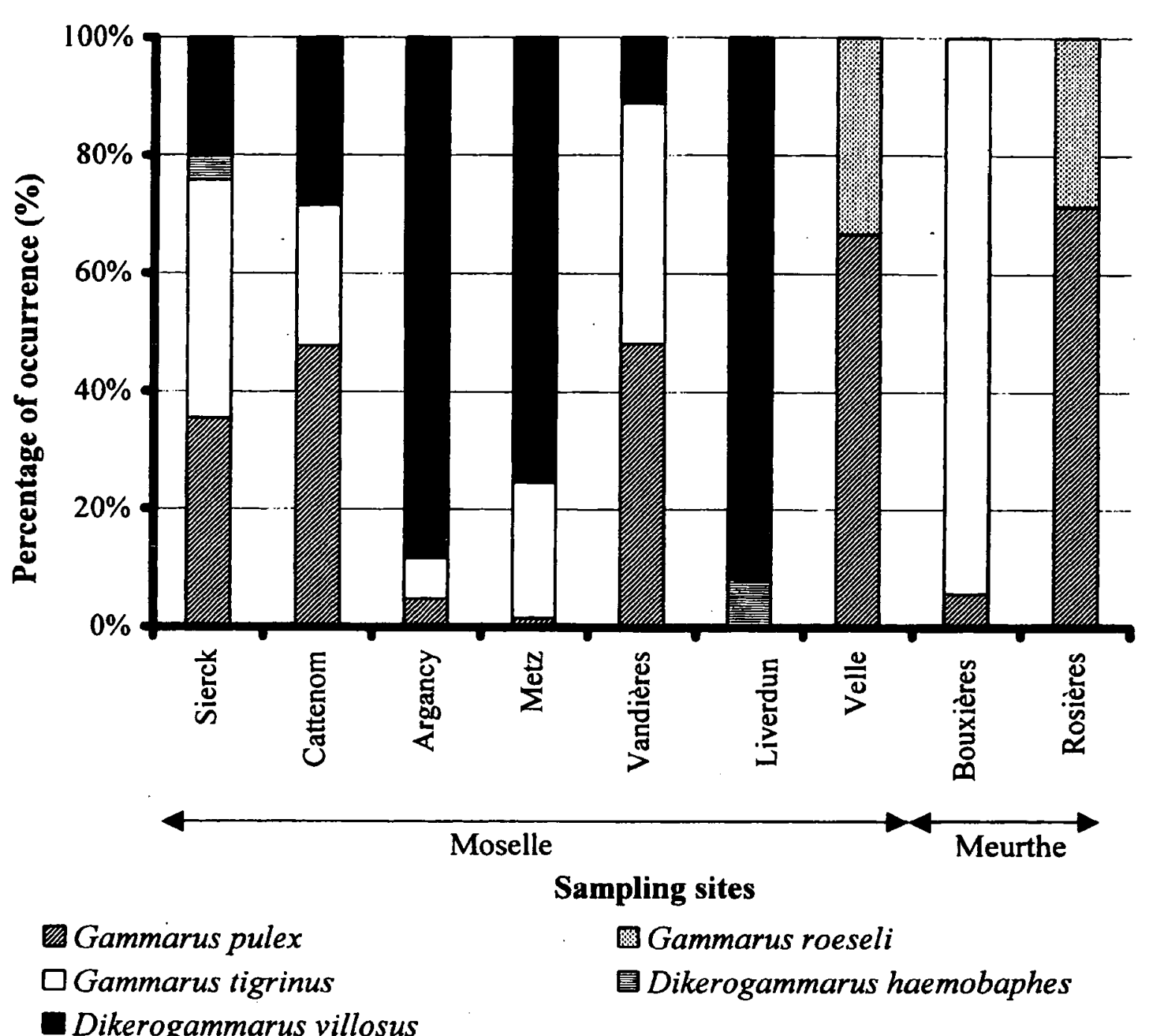

Fig. 2. Proportions of different gammarid species at each of the 9 sampling stations (Rivers Moselle and Meurthe).

Fig. 2. Proportions des différentes espèces de Gammaridae prélevées aux 9 stations d'échantillonnage (Moselle et Meurthe).

Meurthe (Fig. 1). Consequences of this massive establishment on species in place are not yet known. The largest individuals are usually the most aggressive and superior competitors (MacNeil et al. 1997). The large size of $D$. villosus relative to other freshwater amphipods is in part likely to explain its successful predatory behavior (Dick \& Platvoet 2000). 270 specimens of this species were measured in the samples collected at Argancy. The mean length of individuals in the June sample was $10.6 \mathrm{~mm}$, and the maximum size $15.7 \mathrm{~mm}$ (Table 2). The prevailing length of $D$. villosus was 9$13.5 \mathrm{~mm}$, the percentage of adult specimens being very high (Fig. 3 ; Table 2). In other basins, adult males reached up to $30 \mathrm{~mm}$ total body length (Nesemann et al. 1995). Specimens with a maximum size of $21 \mathrm{~mm}$ were found in the Alsace Canal. Concerning the French River Moselle, lengths of $D$. villosus speci- mens were the longest observed among the amphipods collected.

According to Nesemann et al. (1995), the coloration of living animals is highly variable. Three morphs of D. villosus (striped, melanic and amber) can be easily distinguished but this remarkable phenotypic plasticity was scarcely studied. The two dominant groups in number of individuals were by far the striped and the melanic morphs (52.8 and $39.9 \%$ respectively) in the River Moselle. The sex ratio for each morph was generally about $1: 1$ (Table 2 ). The length distribution of the melanic specimens was significantly higher than that of the striped specimens ( $p=0.015 \%$, MannWhitney test). The length distribution of the amber morph seemed to be the shortest, but only 9 individuals were measured. Nesemann et al. (1995) suggested that pale specimens had simply moulted more recently. 
Table 2. Distribution by morph and sex of Dikerogammarus villosus samples from the River Moselle at Argancy in June 2000. Tableau 2. Répartition par morphe et par sexe d'un échantillon de Dikerogammarus villosus de la Moselle à Argancy, en juin 2000.

\begin{tabular}{|c|c|c|c|c|c|}
\hline & Morph & Proportion (\%) & Male (\%) & Female (\%) & $\begin{array}{l}\text { Length in mm } \\
\text { Median } \\
\text { (min.) (max.) }\end{array}$ \\
\hline \multirow[t]{4}{*}{ Adults } & & & 47.7 & 52.3 & $\begin{array}{c}10.7 \\
(5.5)(15.7)\end{array}$ \\
\hline & Striped & 52.8 & 55.2 & 44.8 & $\begin{array}{c}10.5 \\
(5.5)(15.1)\end{array}$ \\
\hline & Melanic & 39.9 & 49.1 & 50.9 & $\begin{array}{c}11.3 \\
(6.2)(15.7)\end{array}$ \\
\hline & Amber & 3.3 & 44.4 & 55.6 & $\begin{array}{c}9.9 \\
(5.6)(13.1)\end{array}$ \\
\hline Youngs & & 4.1 & & & $\begin{array}{c}4.35 \\
(3.7)(5.3)\end{array}$ \\
\hline
\end{tabular}

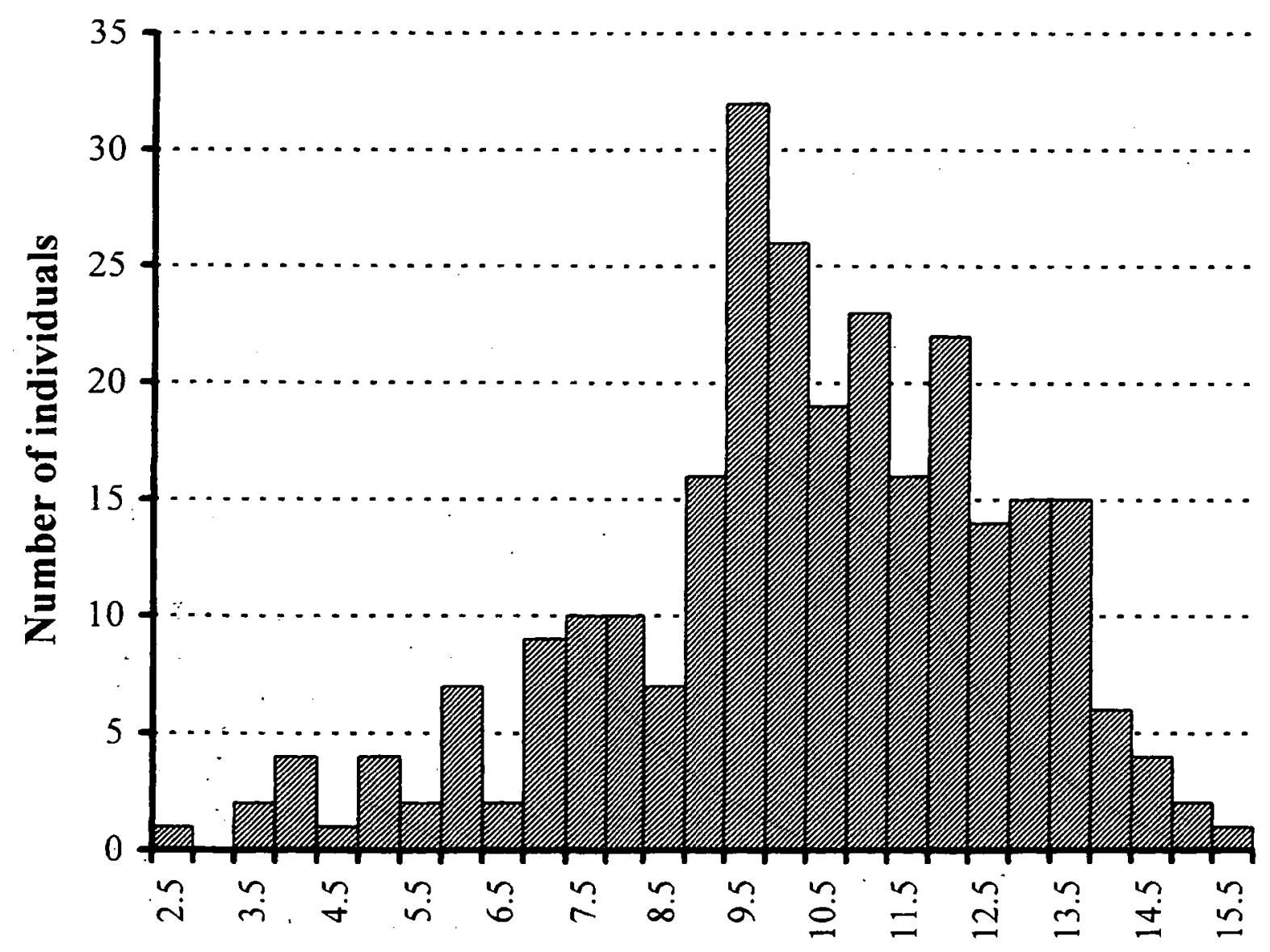

Fig. 3. Length-frequency histogram of Dikerogammarus villosus in the River Moselle at Argancy (sample of June 2000).

Fig. 3. Histogramme de distribution des tailles de Dikerogammarus villosus à Argancy, Moselle (échantillon de juin 2000). 


\section{Conclusion}

Many Ponto-Caspian species colonized the River Moselle and $D$. villosus, recently established, seems to be already a prevailing amphipod species in terms of abundance, even if the river bottom heterogeneity was scarcely considered in our sampling program. The Ponto-Caspian basin could be clearly identified as a donor region considering its disproportionate contribution to the aquatic fauna of French Northeastern ecosystems.

The immigration of Dikerogammarus villosus is probably not stabilized in French hydrosystems and the extended range of this amphipod could reach many other waterways. $D$. villosus has a higher tolerance to high water temperature than Gammarus roeseli (Muskó 1992). Furthermore, D. villosus has a broad salinity tolerance, and can be found in the Azov Sea and in the estuaries of rivers discharging in the Black Sea (Bij de Vaate \& Klink 1995). Due to a particular profile that could facilitate ballast water transport, this invertebrate was identified as a potential invader of worldwide waterways, and could become a cosmopolitan species, like the freshwater mussel Dreissena polymorpha (Ricciardi \& Rasmussen 1998, MacIsaac 1999).

In addition, particular biological traits, such as its reproductive capacity (Van der Velde et al. 2000), favors their rapid population growth in a new territory. Considering its biological and ecological characteristics, $D i$ kerogammarus villosus will probably become a cosmopolitan species in large European rivers. Further researches are currently underway to define the life cycle of this amphipod in our ecosystems and the impact of its establishment on autochthonous macroinvertebrates.

\section{Acknowledgments}

We would like to thank the 'Banque de l'Eau Rhin-Meuse Réseau National des Données sur l'Eau' for the physicochemical data. We are grateful to Dr. Ilona B. Muskó (Balaton Limnological Research, Hungary) and Dr. Abraham Bij de Vaate (RIZA, The Netherlands) for their help in obtaining documents on Dikerogammarus species.

\section{References}

Bachmann V., Cegielka E., Wagner P., Usseglio-Polatera P. \& Moreteau J.C. 1995. - Installation de l'Amphipode Corophium curvis pinum et de la palourde asiatique Corbicula sp. Dans la partie française de la Moselle. Hydroécol. Appl., 7 (1-2) : 185-190.

Bij de Vaate A. \& Greijdanus-Klaas M. 1990. - The Asiatic clam, Corbicula fluminea (Müller, 1774) (Pelecypoda, Corbiculidae), a new immigrant in The Netherlands. Bull. Zool. Mus. Amsterdam, 12 (12) : 3-7.

Bij de Vaate A. \& Hulea O. 2000. - Range extension of the Asiatic clam Corbicula fluminea (Müller 1774) in the River Danube : first record from Romania. Lauterbornia, 38 : 23-26.

Bij De Vaate A.. \& Klink A.G. 1995. - Dikerogammarus villosus Sowinsky (Crustacea : Gammaridae) a new immigrant in the Dutch part of the Lower Rhine. Lauterbornia, $20: 51-54$.

Carausu S., Dobreanu E. \& Manolache C. 1955. - Amphipoda Forme salmastre si de apa dulce. In : Bodnariuc N. et al. (eds). Fauna repubicii populare romîne 4, Crustacea 4, Bucuresti : 1-407.

Dick J.T.A.\& Platvoet D. 2000. - Invading predatory crustacean Dikerogammarus villosus eliminates both native and exotic species. Proc. R. Soc. Lond, B 267 : 977-983.

MacIsaac H.J. 1999. - Biological invasions in Lake Erie : past, present and future : 305-322. In : M. Munawar, T. Edsall \& I.F. Munawar (eds), The State of Lake Erie (SOLE) - Past, Present and Future - A tribute to Drs. Joe Leach \& Henry Regier. Backhuys Publishers, The Netherlands : $533 \mathrm{p}$.

MacNeil C., Dick J.T.A., \& Elwood R.W. 1997. - The trophic ecology of freshwater Gammarus spp. (Crustacea : Amphipoda) : problems and perspectives concerning the functional feeding group concept. Biol. Rev,. 72 : 349-364.

Muskó I.B. 1992. - Amphipoda species found in lake Balaton since 1987. Miscnea. Zool. Hung., 7 : 59-64.

Muskó I.B. 1993. - The life history of Dikerogammarus haemobaphes (EICHW.) (Crustacea : Amphipoda) living on macrophytes in Lake Balaton (Hungary). Arch. Hydrobiol., 127 (2) : 227-238.

Nesemann H., Pockl M. \& Wittmann K.J. 1995. - Distribution of epigean Malacostraca in the middle and upper Danube (Hungary, Austria, Germany). Miscnea. Zool. Hung., $10: 49-68$.

Ricciardi A. \& MacIsaac H. J. 2000. - Recent mass invasion of the North American Great Lakes by Ponto-Caspian species. Trends Ecol. Evol., 15 : 62-65.

Ricciardi A. \& Rasmussen J. B. 1998. - Predicting the identity and impact of future biological invaders : a priority for aquatic resource management. Can. J. Fish. Aquat. Sci., 55: 1759-1765.

Tittizer T. \& Taxacher M. 1997. - Erstnachweis von Corbicula fluminea/fluminalis (Müller 1774) (Corbiculidae, Mollusca) in der Donau. Lauterbornia, 31 : 103-107.

Van der Velde G., Rajagopal S., Kelleher B., Muskó I.B., \& Bij de Vaate A. 2000. - Ecological impacts of crustacean invaders : general considerations and examples from the Rhine river. Crustacean Issues, 12 : 3-33. 